\title{
ANALYSIS OF DOMAIN MONITORING AND EVALUATION COBIT MATURITY LEVEL IN GAME DEVELOPMENT COMPANY
}

\author{
Putri Nastiti ${ }^{1 *}$, Kathryn Widhiyanti ${ }^{2}$ \\ Department of Informatics \\ Universitas Atma Jaya Yogyakarta \\ putri.nastiti@uajy.ac.id ${ }^{1 *}$ ) \\ Study Program of Animation \\ Institut Seni Indonesia Yogyakarta \\ kathryn@isi.ac.id \\ ${ }^{*}$ ) Corresponding Author
}

\begin{abstract}
Abstrak
Banyak anggapan bahwa tata kelola teknologi informasi hanya cocok diterapkan oleh perusahaan berskala besar. Namun hal ini tidak terbukti benar. Banyak perusahaan rintisan skala kecil dan menengah mengalami kegagalan karena tidak mempunyai perencanaan tata kelola yang baik. Hal ini berarti bahwa perusahaan skala kecil dan menengah pun juga membutuhkan perencanaan penerapan TI yang tepat. Tujuan penelitian ini adalah untuk mengukur tingkat kematangan tata kelola teknologi informasi, khususnya dalam hal monitoring dan evaluasi kinerja TI, penerapan kontrol internal, serta kepatuhan terhadap peraturan eksternal perusahaan. Berdasarkan perhitungan, perusahaan pengembang game ini berada di tingkat kematangan 3 (Defined Process). Selain itu ditemukan kesenjangan yang paling besar ada di atribut Skill and Expertise dan atribut Goals and Measurement. Penelitian ini juga memberikan rekomendasi untuk perusahaan berdasarkan analisis kesenjangan pada masing-masing proses.
\end{abstract}

Kata kunci: kematangan tata kelola TI, COBIT, domain ME

\begin{abstract}
There are many opinions that information technology governance is only suitable to be applied by largescale companies. However, this has not been proven to be true. Many small and medium-sized startups fail because they do not have good governance plans. This means that even small and medium-sized companies also need proper IT implementation planning. The purpose of this study was to measure the maturity level of information technology governance, particularly in terms of monitoring and evaluating IT performance, implementing internal controls, and compliance with company external regulations. Based on calculations, this game development company is at maturity level 3 (Defined Process). In addition, it was found that the biggest gap was in the Skill and Expertise attributes and the Goals and Measurement attributes. This study also provides recommendations for companies based on gap analysis in each process.
\end{abstract}

Keywords: IT governance maturity, COBIT, domain ME

\section{INTRODUCTION}

Advances in information and communication technology bring the development of creative industries in Indonesia. The creative industry is an industry that originates from the utilization of individual skills, creativity, and talents in creating prosperity and employment. This industry focuses on empowering the creativity and creativity of an individual (Bekraf, 2020). The creative industry in Indonesia is certainly spread across various company scales ranging from small to large. One of the creative industries that will be discussed in this research is the game industry. In the period 2016 to 2019, there were many video game development companies were established. However, not a few are finally closed, especially those that are independent. There are only around 30 game development companies that are legal entities or middle to large class in Indonesia (Bestari, 2021). According to BEKRAF's annual report, until 2019 there were more than 49 thousand workers in the application and game developer sub-sector, and at least more than 10 game development companies were participating in overseas exhibitions (Bekraf, 2020). This game 
development company must continue to innovate to compete in the market. Innovation can be done not only in product innovation, but also in other forms such as process innovation, business model innovation, organizational structure, marketing, management systems, and customer service (Aryanto et al., 2015; Powell, 1992).

In research (Politowski et al., 2021) mentioned several dynamics of problems experienced by game development companies, including those related to managerial, technical problems, game design, and production, marketing But most of the main root causes are related to people, not technology. This of course requires careful strategic planning or governance, both in terms of business and IT strategy. Information technology governance in small and medium-sized companies is something that is still rarely discussed. Many studies related to this topic refer to large companies (Silva et al., 2020).

IT governance is a broad concept centered on the IT department or environment that provides business value to the company. It is a set of rules, regulations, and policies that define and ensure the effective, controlled, and valued operation of the IT department. IT governance also provides methods for identifying and evaluating IT performance and how it relates to business growth (Castellanos, 2021).

Many assume that information technology governance is only suitable for large-scale companies (Bergeron et al., 2015). However, this is not entirely true. Even small and medium-sized companies need proper IT implementation planning. The context of failure in IT implementation also does not always have to be about a technology that fails to develop as expected. The point of failure of implementation could be in the form of stakeholder perceptions that have not been connected.

COBIT is a framework that is often used by companies as a tool to measure the maturity level of information technology governance. COBIT provides a comprehensive framework that assists companies in achieving corporate IT governance and management objectives (Amorim et al., 2021). COBIT is also general in nature and can be applied to small to large companies, whether commercial, not-for-profit, or in the public sector (ISACA. \& Lainhart, 2012), (Bernroider \& Ivanov, 2011). This study aims to measure the level of maturity, especially in the domain of monitoring and evaluating IT governance in a medium-scale game development company.

\section{RESEARCH METHODS}

This study uses a qualitative descriptive analysis method, namely analyzing, describing, and summarizing various conditions, situations from various data collected in the form of interviews or observations about the problems studied that occur in the field (Nassaji, 2015). The game development company that is the object of this research is CV Sophismata Global Indotama, which is located in the city of Yogyakarta. The determination of respondents in this study considers the capability or ability to answer questions and determine the maturity scale of IS/IT governance in game development companies. Therefore selected respondents who are the top management of the company.

\section{Data, Instruments, and Data Collection Techniques}

Data collection consisted of interviews, observations, and filling out maturity questionnaires. Interviews were conducted to obtain more information from top management regarding the research topic in more depth. Researchers collected data using structured interview techniques. Guidelines used in conducting interviews in the form of questions related to the assessment of the maturity level of information systems. In addition, the questionnaire used in this study was compiled based on six maturity criteria based on the COBIT standard (Institute, 2007). The results of this questionnaire will be used as a reference for researchers in providing recommendations to organizations regarding matters that need to be improved. This questionnaire contains 36 attribute questions related to the assessment of governance maturity for the ME process. The answers described by the respondents will be assessed using a Likert scale where a scale of 0-5 is explained as in table 1:

Table 1. Generic Maturity Model

\begin{tabular}{ll}
\hline Maturity Level & Description \\
\hline 0 (Non-existent) & $\begin{array}{l}\text { The enterprise has not } \\
\text { even recognized that } \\
\text { there is an issue to be } \\
\text { addressed. }\end{array}$ \\
\hline 1 (Initial/Ad Hoc) & There are no \\
& standardized processes; \\
& instead, there are ad hoc \\
& approaches that tend to \\
& be applied on an \\
& individual or case-by- \\
& case basis. The overall \\
& approach to management \\
& is disorganized. \\
\hline
\end{tabular}




\begin{tabular}{|c|c|}
\hline Maturity Level & Description \\
\hline $\begin{array}{l}2 \text { (Repeatable but } \\
\text { Intuitive) }\end{array}$ & $\begin{array}{l}\text { There is no formal } \\
\text { training } \\
\text { communication or } \\
\text { standard procedures, and } \\
\text { responsibility is left to } \\
\text { the individual. }\end{array}$ \\
\hline 3 (Defined Process) & $\begin{array}{lr}\text { Procedures have been } \\
\text { standardized } & \text { and } \\
\text { documented } & \text { and } \\
\text { communicated } & \text { through } \\
\text { training. } & \\
\end{array}$ \\
\hline $\begin{array}{l}4 \quad \text { (Managed and } \\
\text { Measurable) }\end{array}$ & $\begin{array}{l}\text { Management monitors } \\
\text { and measures } \\
\text { compliance with } \\
\text { procedures and takes } \\
\text { action where processes } \\
\text { appear not to be working } \\
\text { effectively. }\end{array}$ \\
\hline 5 (Optimised) & $\begin{array}{l}\text { Processes have been } \\
\text { refined to a level of good } \\
\text { practice, based on the } \\
\text { results of continuous } \\
\text { improvement and } \\
\text { maturity modeling with } \\
\text { other enterprises. }\end{array}$ \\
\hline
\end{tabular}

Source: COBIT 4.1 IT Governance Institute (Institute, 2007)

\section{Procedure}

Data analysis is divided into two, namely maturity level analysis and gap analysis. Maturity level analysis was carried out based on the results of questionnaires and interviews regarding the maturity level of an information system contained in the organization. Gap analysis is carried out from the results of the analysis of the results of the questionnaire which has resulted in the difference between the current organizational conditions and the organization's expectations in the future. The last step is to make recommendations. Recommendations are made based on the gap between the current maturity level and the company's expected maturity level. Recommendations are made to provide suggestions for improving the company's IS/IT governance. Improvement decisions will be left to top management to decide whether the recommendations will be implemented within the company or not. This research flow is as in Figure 1.

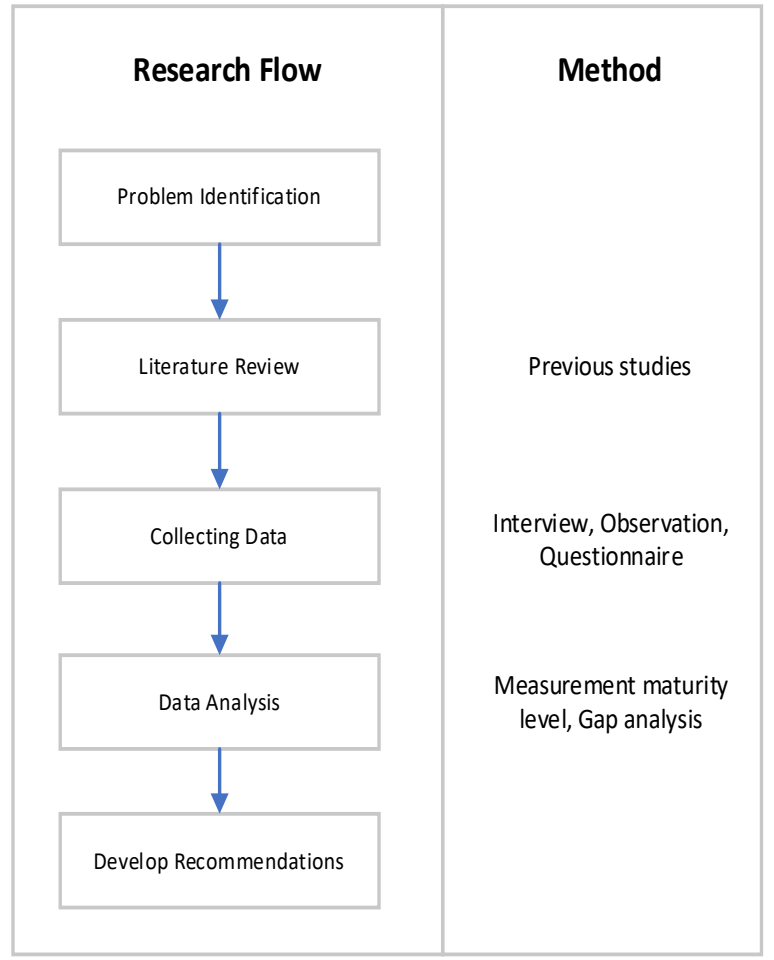

Figure 1. Research flow

\section{RESULTS AND DISCUSSION}

Based on the results of filling out questionnaires and interviews that have been conducted with the top management of the three-game development companies, the results of the calculation of the maturity level of the monitor and evaluation process are obtained. The calculation of the ME domain maturity level value is calculated by adding up each maturity value of each attribute and then dividing by the total number of attributes of each maturity process.

From table 2 it is known that the average maturity of the ME domain is 2.8 or is at level 3 . The average maturity level of the ME domain obtained is based on the results of the calculation of 3 processes, each process consisting of 6 attributes used in the ME domain. determine the value of each process in the ME domain. The following is a detailed explanation for each process in the ME domain.

Table 2. Sophismata Maturity Level in Domain ME

\begin{tabular}{|c|c|c|c|c|c|c|c|c|}
\hline \multirow[b]{2}{*}{ No } & \multirow[b]{2}{*}{ Proses } & \multicolumn{6}{|c|}{ Atribut } & \multirow{2}{*}{$\begin{array}{l}\text { Maturity } \\
\text { Level }\end{array}$} \\
\hline & & AC & PPP & TA & SE & RA & GSM & \\
\hline 1 & ME 1 & 3 & 3 & 3 & 2 & 3 & 2 & 3.2 \\
\hline 2 & ME 2 & 2 & 3 & 3 & 2 & 3 & 2 & 3 \\
\hline 3 & ME 3 & 2 & 2 & 1 & 2 & 2 & 2 & 2.2 \\
\hline \multicolumn{8}{|c|}{ Average maturity domain $\mathrm{ME}$} & 2.8 \\
\hline
\end{tabular}




\section{Monitor and Evaluate IT Performance (ME 1)}

Table 3. Domain ME 1

\begin{tabular}{clccc}
\hline No & Atribut Kematangan & as-is & to-be & Gap \\
\hline 1 & $\begin{array}{l}\text { Awareness and } \\
\text { Communication }\end{array}$ & 3 & 4 & 1 \\
2 & $\begin{array}{l}\text { Policies, Plan and } \\
\text { Procedures }\end{array}$ & 3 & 4 & 1 \\
3 & $\begin{array}{l}\text { Tools and } \\
\text { Automation }\end{array}$ & 3 & 4 & 1 \\
5 & $\begin{array}{l}\text { Skills and Expertise } \\
\text { Responsibilities and } \\
\text { Accountabilities }\end{array}$ & 2 & 4 & 2 \\
6 & $\begin{array}{l}\text { Goal Setting and } \\
\text { Measurement }\end{array}$ & 2 & 4 & 2 \\
\hline Average maturity & 2.6 & 4 & 1.8 \\
\hline
\end{tabular}

Table 3 shows the maturity value of ME 1 , which is regarding monitoring and evaluation of IT performance in game development companies, and the average value is 2.6 or is at the maturity level 3 . Maturity level 3 (Defined Process) on ME 1 means that the company's management has communicated standard monitoring processes. A training program for performance monitoring has also been implemented. Assessment is still carried out on each IT process and is not integrated among all processes. Tools to monitor IT processes and how service levels are defined. The measurement of the contribution of the information service function to organizational performance has been determined, as well as the measurement of the performance of other functional areas such as finance, marketing, production, and customer satisfaction measurements have been determined.

Based on the results of interviews with the director of Sophismata, currently, they have implemented standards and criteria in performance measurement, such as ISO 27001 and OSI layer. ISO 27001 and OSI layers are used to maintain information security. In addition to measuring financial performance using basic standards of bookkeeping and balance sheets supported by Ms. Excel. Sophistama also applies affinity testing, user testing, and behavioral testing evaluation methods to find out how users accept the games they develop.

In general, this game development company has been using the task list method and WBS (work break-down structure) in managing the company's performance. The performance of the company referred to here covers all functional areas of the company. While the tools used to support the performance measurement method are Ms. Office like Ms. Excel and Ms. Words. The tools currently used are not yet by the standards for measuring company performance. However, the output of the method currently applied by the company is a matrix of data on employee performance, financial accounting, and balance sheets.

In addition to measuring performance in more technical IT fields such as network / IT network, the company uses Winbox tools. Winbox application is a utility that is used for MikroTik connectivity and configuration using MAC Address or IP protocol. Through this application, the company will get results in the form of a data matrix. The data obtained can later be used by top management (or in this case is the director) to measure the company's IT performance. Meanwhile, to measure customer satisfaction, what has been done by game development companies at this time is to take advantage of the questionnaire feature that has been provided by the distribution platform, for example, the questionnaire on the Playstore. It is quite effective and efficient to find out how the level of user acceptance of the product from this game development company is.

\section{Monitor and Evaluate Internal Control (ME 2)}

Table 4. Domain ME 2

\begin{tabular}{clccc}
\hline No & \multicolumn{1}{c}{$\begin{array}{c}\text { Atribut } \\
\text { Kematangan }\end{array}$} & as-is & to-be & Gap \\
\hline 1 & $\begin{array}{l}\text { Awareness and } \\
\text { Communication }\end{array}$ & 2 & 4 & 2 \\
2 & $\begin{array}{l}\text { Policies, Plan and } \\
\text { Procedures }\end{array}$ & 3 & 4 & 1 \\
3 & $\begin{array}{l}\text { Tools and } \\
\text { Automation }\end{array}$ & 3 & 5 & 2 \\
4 & $\begin{array}{l}\text { Skills and Expertise } \\
\text { Responsibilities and } \\
\text { Accountabilities }\end{array}$ & 2 & 4 & 2 \\
6 & $\begin{array}{l}\text { Goal Setting and } \\
\text { Measurement }\end{array}$ & 2 & 4 & 1 \\
\hline Average maturity & 2.5 & 4.2 & 1.7 \\
\hline
\end{tabular}

Table 4 shows the maturity level of ME 2, which is regarding the monitoring and evaluation of internal controls within the game development company, and the average value is 2.5 or is at level 3. Maturity level 3 (Defined Process) in ME 2 means that the company's management has supported internal control monitoring. Policies and procedures are developed to assess and report on internal control monitoring activities. A training program for internal control monitoring has also been established.

Policies related to internal control have been made by Sophistama's top management. This policy is also a procedure that is ready to be carried out by all members of the company and is 
accompanied by activity reporting. There are two main job categories at Sophistama, namely one-time projects, and routine work. The internal control policy made for each one-time project activity is to use WBS (work break-down structure), supported by the Ms. Excel as a logbook to detail all the work to be done and who and what divisions will be involved. In addition, records are also made for the parties responsible for each phase. WBS is the basis for implementing work that applies agile development methods. The other category is routine work. In this type of work, the policies, procedures, and reporting still use manual scheduling using the mind map and fishbone methods which are supported by the Ms. Offices. Details of each daily or routine work will be reported through the team lead for each section. Furthermore, by the team lead, the report will be forwarded to the manager and every week reported to the director.

\section{Ensure Compliance with External Requirements (ME 3)}

Table 5. Domain ME 3

\begin{tabular}{clccc}
\hline No & Atribut Kematangan & as-is & to-be & Gap \\
\hline 1 & $\begin{array}{l}\text { Awareness and } \\
\text { Communication }\end{array}$ & 2 & 4 & 2 \\
2 & $\begin{array}{l}\text { Policies, Plan and } \\
\text { Procedures }\end{array}$ & 2 & 4 & 2 \\
3 & $\begin{array}{l}\text { Tools and Automation } \\
4\end{array}$ & 1 & 4 & 3 \\
5 & $\begin{array}{l}\text { Skills and Expertise } \\
\text { Responsibilities and }\end{array}$ & 2 & 4 & 2 \\
& $\begin{array}{l}\text { Accountabilities } \\
6\end{array}$ & 2 & 4 & 2 \\
Goal Setting and & Measurement & 2 & 4 & 2 \\
\hline Average maturity & 1.8 & 4 & 2.2 \\
\hline
\end{tabular}

Table 5 shows the maturity level of ME 3 which is regarding the process of ensuring the company's compliance with external requirements, such as with laws, regulations, and contractual requirements, and those relating to external parties. From the calculation results, the average value is 1.8 or is at level 2. Maturity level 2 (Repeatable but Intuitive) on $\mathrm{ME} 3$ means the company has understood the need to comply with external requirements, and these needs have been communicated. Where compliance is a recurring requirement, such as in financial regulations or privacy laws, individual compliance procedures have been developed and followed year after year. However, there is no standard approach.

Sophismata has been established in July 2020. As a new game development company, but is already a legal entity, in terms of individual compliance, it uses organizational structure procedures that detail the flow of information from leaders to employees and vice versa. The form of performance rules and responsibilities is stated in a contract document that has been agreed upon by the employer and the employee as the executor of the work. Companies and employees also have rights and obligations by the laws and regulations set by the government. Currently, the company is developing proper procedures for the type of work that can be done outside the office (remote working). The company still has weaknesses in terms of the distribution of information for remote job criteria.

\section{Gap Analysis}

Table 6. Gap Analysis Domain ME

\begin{tabular}{clccc}
\hline No & Atribut Kematangan & as-is & to-be & Gap \\
\hline 1 & $\begin{array}{l}\text { Awareness and } \\
\text { Communication }\end{array}$ & 2.3 & 4 & 1.7 \\
2 & $\begin{array}{l}\text { Policies, Plan, and } \\
\text { Procedures }\end{array}$ & 2.6 & 4 & 1.4 \\
3 & $\begin{array}{l}\text { Tools and } \\
\text { Automation }\end{array}$ & 2.3 & 4 & 1.7 \\
5 & $\begin{array}{l}\text { Skills and Expertise } \\
\text { Responsibilities and }\end{array}$ & 2 & 4 & 2 \\
6 & $\begin{array}{l}\text { Accountabilities } \\
\text { Goal Setting and } \\
\text { Measurement }\end{array}$ & 2.6 & 4 & 1.4 \\
\hline Average maturity & 2.3 & 4 & 1.7 \\
\hline
\end{tabular}

Based on table 4.5, it can be seen that in the ME domain there is an average gap of 1.7 . The average obtained is the result of the calculation of the 6 attributes used to determine the value of each process in the ME domain. There is no big gap for each maturity attribute. The two attributes that have the largest gap values are Skills and Expertise and Goal Setting and Measurement. The visualization of gap analysis as shown in figure 2.

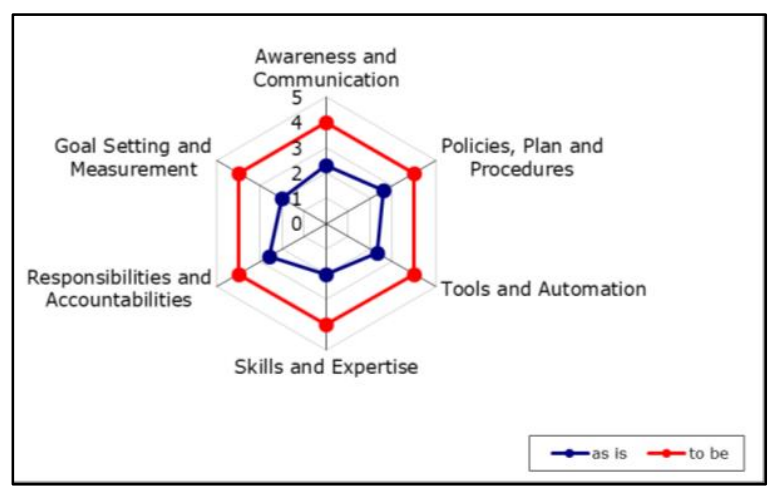

Figure 2. Gap Analysis of Domain ME

\section{Skill and Expertise:}

Based on the questionnaires and interviews, Sophismata is currently at level 2 in 
terms of skill and expertise maturity. This means that the company's management has identified and set the minimum standard of expertise required for critical areas of the company. The critical areas referred to here are those that run the company's core business, or those that are directly related to the product development process. In addition, about training, at this maturity level, the company already has awareness that training is provided in response to needs, but its implementation is still carried out informally.

Furthermore, Sophismata hopes to reach maturity level 4. At this level, documentation of the list of required human resource skills has been regularly updated for all areas, a list of skill requirements has also been confirmed for all critical areas of the company, as well as certification. has also been recommended for employees. In addition, about training, at this expected maturity level, companies need to ensure that the training must be implemented based on the training plan, besides that knowledge sharing also needs to be implemented. The level of effectiveness of the training implementation must also be measured.

\section{Goals Setting and Measurement:}

As well as the skill and expertise, currently, Sophismata is also at level 2 in terms of goals and measurement maturity. This means that the company has started to list the company's achievements, which are accompanied by related financial measurements but are only known to the top management level. In addition, monitoring has also been carried out, but only inconsistently and only in certain areas.

Based on the questionnaires and interviews, Sophismata hopes to reach maturity level 4. At this level, the company's goals from both an IT and business point of view must be in line. The effectiveness and efficiency of IT performance need to be measured and communicated as well as in line with business goals and IT strategic plans. At this level, the company's performance measurement is carried out by applying the IT Balanced Scorecard dimensions, namely user orientation, business value, operational excellence, and future orientation. In addition, the implementation of root causes analysis has been standardized, and continuous improvement has started to be implemented.

\section{Improvement Recommendation}

By looking at the analysis of game development companies, the researchers provide several recommendations that can be used as references to make improvements related to IS/IT governance in the future. There are two proposed recommendations, namely:

1. The proposed recommendation for Sophismata's top management is the application of the IT Balanced Scorecard framework. Currently, Sophismata has started to measure IT performance but has not yet used a measurement standard, so performance measurement is still done informally. The IT Balanced Scorecard is a tool to measure the performance of information technology which views the information technology business unit from 4 perspectives, namely: user orientation perspective, business contribution perspective, operational excellence perspective, and future orientation perspective. This tool is also used to measure the alignment between IT and business performance of the company (Herdiansyah et al., 2014). From these four perspectives then top management can create a company IT strategy map (Setiabudiarto, 2020). This strategy map can be reduced to various KPIs (key performance indicators) for all product development teams. If all teams already have their own KPIs, then the performance measurement for all teams will be more systematic.

2. Currently, the internal control carried out by Sophismata's top management for two main activity categories, namely one-time projects, and routine or daily work can be said to be still manual, such as the use of Ms. Excel for the logbook that records all tasks and who is responsible. This is certainly less effective and efficient, so it is proposed to use a task management application, one example is Trello. Trello is a collaboration application that allows all the teams involved to manage various projects in one place. By using Trello, all parties on the project team can find out what the team is working on, who is working on it, and how far they have been working on it. The use of this application will support the game development system that has been implemented in Sophismata. This is a simple automation proposal that is possible even for small game development companies. In addition, of course, it is also necessary to consider training for employees to use task management applications (Wolter, 2018). Hoda stated in her research that the development teams will get benefit from these digital agile task management tools, such as Jira, Trello, or Scrumwise (Hoda \& Murugesan, 2016). 


\section{CONCLUSIONS AND SUGGESTIONS}

\section{Conclusion}

Based on the calculation of the results of the ME domain maturity level analysis using COBIT, it is known that the game development company is at level 3 (Defined Process). At this maturity level, the company has made standard procedures and has been documented, and communicated through training. The procedures carried out are not sophisticated but are a formalization of existing practices. Gap analysis is also carried out for each process, and it is known that the ME1 (Monitor and Evaluate IT Performance) process has a gap of 1.8, ME2 (Monitor and Evaluate Internal Control) has a gap of 1.7, and ME3 (Ensure Compliance with External Requirements) has a gap of 2.2. No gap is too large for the three processes in this game development company. Based on the gap analysis, several recommendations for improvement are proposed, including the use of task management such as Trello to automate team performance monitoring, as well as performance evaluation using the IT BSC standard.

\section{Suggestion}

This research can be developed further by measuring the capability level of IT governance from the same domain in game development companies.

\section{REFERENCES}

Amorim, A. C., Mira da Silva, M., Pereira, R., \& Gonçalves, M. (2021). Using agile methodologies for adopting COBIT. Information Systems, 101(xxx), 101496. https://doi.org/10.1016/j.is.2020.101496

Aryanto, R., Fontana, A., \& Afiff, A. Z. (2015). Strategic Human Resource Management, Innovation Capability and Performance: An Empirical Study in Indonesia Software Industry. Procedia - Social and Behavioral Sciences, 211(September), 874-879. https://doi.org/10.1016/j.sbspro.2015.11.11 5

Bekraf. (2020). Laporan Kerja Badan EKonomi Kreatif. 148, 148-162.

Bergeron, F., Croteau, A.-M., Uwizeyemungu, S., \& Raymond, L. (2015). IT Governance Framework Applied to SMEs. International Journal of IT/Business Alignment and Governance, 6(1), 33-49. https://doi.org/10.4018/ijitbag.2015010103

Bernroider, E. W. N., \& Ivanov, M. (2011). IT project management control and the Control Objectives for IT and related Technology
(CobiT) framework. International Journal of Project Management, 29(3), 325-336. https://doi.org/10.1016/j.ijproman.2010.03. 002

Bestari, N. P. (2021). Miris! Pasar Game RI Rp 60 Triliun, Lokal Hanya Kuasai 0.4\%. CNBC Indonesia.

https://www.cnbcindonesia.com/tech/2021 0422144533-37-240024/miris-pasar-gameri-rp-60-triliun-lokal-hanya-kuasai-04

Castellanos, W. S. (2021). Impact of Information Technology (IT) Governance on Business-IT Alignment. Cuadernos de Gestion, 21(2), 8396. https://doi.org/10.5295/cdg.180995ws

Herdiansyah, M. I., Kunang, S. O., \& Akbar, M. (2014). It strategy alignment in university using it balanced scorecard framework. Advanced Science Letters, 20(10-12), 2038-2041. https://doi.org/10.1166/asl.2014.5685

Hoda, R., \& Murugesan. (2016). Multi-Level Agile Project Management Challenges: A SelfOrganizing Team Perspective. Journal of Systems and Software.

Institute, I. G. (2007). Ch4.1 - Cobit 4.1. In Governance An International Journal of Policy And Administration. http://scholar.google.com/scholar?hl=en\&bt $\mathrm{nG}=$ Search\&q=intitle:Framework+Control+O bjectives+Management+Guidelines+Maturity +Models\#4

ISACA., \& Lainhart, J. W. (2012). COBIT 5: A business framework for the governance and management of enterprise IT COBIT 5. In United States of America: ISACA (Vol. 34, Issue 1).

http://tp.revistas.csic.es/index.php/tp/articl e/viewArticle/432\%0Ahttp://files/399/432. html

Nassaji, H. (2015). Qualitative and descriptive research: Data type versus data analysis. Language Teaching Research, 19(2), 129-132. https://doi.org/10.1177/136216881557274 7

Politowski, C., Petrillo, F., Ullmann, G. C., \& Guéhéneuc, Y. G. (2021). Game industry problems: An extensive analysis of the gray literature. Information and Software Technology, 134(February), 106538. https://doi.org/10.1016/j.infsof.2021.10653 8

Powell, T. C. (1992). Organizational alignment as competitive advantage. Strategic Management Journal, 13(2), 119-134. https://doi.org/10.1002/smj.4250130204

Setiabudiarto, N. (2020). Peta Strategi Teknologi Informasi. 2, 175-185.

Silva, H. C. C. da, Silveira, D. S. da, Dornelas, J. S., \& 
Ferreira, H. S. (2020). Information Technology Governance in Small and Medium Enterprises - a Systematic Mapping. Journal of Information Systems and Technology Management, 17, 116. https://doi.org/10.4301/s1807-
1775202017001

Wolter, L. (2018). The Feeling and Perception of Using Analog and Digital Task Management Tools within Agile Development. http://ls00012.mah.se/handle/2043/26806 